Postprint.

For published article see:

Xiao, J. J., \& Yao, R. (2020). Debt types and burdens by family structures. International Journal of

Bank Marketing. Published online. https://doi.org/10.1108/IJBM-07-2019-0262

\title{
Debt Types and Burdens by Family Structures
}

\begin{abstract}
- Purpose: The purpose of this study is to examine family structure differences in debt types and burdens of American families.

- Design/methodology/approach: Data are obtained from the 2016 Survey of Consumer Finances. Eight types of family structures, five specific debts, and two debt burden indicators are examined with multivariate logistic regressions.

- Findings: After controlling for several socioeconomic variables, multivariate logistic regression results show that married with children families are more likely than five other family types to have any debt. In terms of specific debts, married with children families are more likely than six other types of families to have mortgages, four other types to have credit card loans, five other types to have to vehicle loans, three other types to have education loans, and one other type to have purchase loans. Married with children families are more likely than three other types of families (childless married couples, single males, and single females) to be late in debt payment for 60 or more days.

- Research limitations/implications: The data are limited to one-year cross sectional data. To gain more insights on this topic, panel data could be used.

- Practical implications: The findings can be used for financial service professionals to identify loan demand and risk associated with various family structures and develop effective marketing strategies to serve these clients.

- Social implications: The findings are informative for public policy makers to develop family-friendly economic policies and for consumer educators who help consumers make effective financial decisions when borrowing various types of loans.

- Originality/value: First, this study uses an innovative definition of family structure that counts several nontraditional family structures. Second, this study examines family structure differences in holdings of five specific debts together.
\end{abstract}

Keywords: debt, debt burden, family structure, Survey of Consumer Finance 


\section{Introduction}

Financial service professionals should benefit the society and serve the interests of their clients (Zingales, 2015). To effectively market financial products to consumers, financial service professionals need to pay attention to new issues in consumer finance (Estelami, 2018; Tufano, 2016) and new trends in consumer market segments (Limbu \& Sato, 2019; Zainudin, Mahdzan, \& Yeap, 2019). This study is relevant to a broad category of financial service, consumer loan service, and also family structure, an important consumer demographic characteristic that can be used to segment consumer markets.

Debt plays a unique role in consumer economic well-being. If managed well, debt can be used to smooth consumption over the life cycle. For example, by utilizing a mortgage, families with limited wealth can afford to purchase a home. Similarly, student loans make higher education more affordable to many families. However, if uncontrolled, debt can disrupt one's economic life and cause economic, social, and psychological distresses. Furthermore, massive consumer debt delinquencies and defaults can affect the health of the entire economy (Kroszner \& Strahan, 2014). Financial innovations increased consumer access to credit and expanded their choices of financial products, but also demanded a higher level of financial literacy and risk management skills (Ryan, Trumbull, \& Tufano, 2010). Failures in the subprime mortgage market in 2008 caused credit markets to tighten and triggered the most severe economic crisis since the Great Depression. Additionally, the economic well-being of many families declined alongside the deregulation of credit markets (Dynan, 2009; Lander, 2016). However, a comprehensive study that includes all types of loans in the context of consumer economic well-being is lacking in literature. 
Demands for different types of loans may differ among families with various structures. Family structures can be categorized in terms of marital status, gender of household head, and presence of children. In recent years, more nontraditional family types emerged such as cohabiting, single mother, and single father families (Cancian \& Reed, 2009; Hemez \& Manning, 2017), which were not included in government issued statistics (e.g. Bricker et al. 2017). How these traditional and nontraditional families demand various types of loans should be of interest to financial service professionals, public policy makers, and consumer educators, but systematic research on debt among various family structures is limited.

To inform stakeholders of consumer finance, comprehensive research on debt related indicators by family structure is necessary. The purpose of this study is to examine family structure differences in debt types and burdens of American families using the latest available national data, the 2016 Survey of Consumer Finance. Unlike Federal Reserve reports, this study used a unique definition of family structure that was based on the family head's marital status and gender, as well as presence of dependent children in the family.

This study contributes to the literature in two aspects. First, this study uses an innovative definition of family structure that counts several nontraditional family structures, which has practical implications for business practice and public policy. Second, this study examines family structure differences in five specific types of debts together that, to our knowledge, has not been done before and will enrich the research literature.

\section{Literature Review}

\section{Debt and Consumer Economic Well-being}

In modern society, especially developed economies, the consumer credit market is highly developed and consumers usually rely on debt for major products or services such as housing 
and higher education to live a normal life ("normal" means a significant portion of people are doing it). In this sense, consumer access to loans is a positive indicator of economic well-being. On the other hand, debt becomes problematic when it gets out of control. If debt is managed poorly and becomes a burden, families have to suffer consequences such as late fees, interest on unpaid balance, reduced credit scores that prevent future access to loans, and increase costs to borrow, which decrease their economic well-being (Bricker et al., 2017; Xiao, 2015).

Borrowing means transferring expected future resources for the use in the present period (Bryant \& Zick, 2006). Having debt is normal in the U.S. In 2016, 77\% of American families had some debt (Bricker et al. 2017). Although borrowing contributes to many families' economic well-being by raising their current standard of living, financial difficulties due to mismanagement of debt were experienced by significant portions of American families. In 2016, $7 \%$ of American families had heavy debt payment to income ratios ( $40 \%$ or higher) and $5.8 \%$ of families missed debt payments for 60 or more days (Bricker et al., 2017). Extensive research shows the importance of financial education and documents the correlations between financial knowledge, debt behavior, and economic well-being. Research shows that the least financially literate people are more likely to have costly mortgages (Moore, 2003). Those with low financial knowledge who are unable to correctly calculate interest rates out of a stream of payments end up borrowing more and accumulating less wealth (Stango \& Zinman, 2009). The less knowledgeable people also use high-cost loans, have excessive debt loads, and are unable to judge their debt positions (Lusardi \& Tufano, 2015). Credit card knowledge can help reduce misuse of credit card and increase financial well-being of young adults (Limbu \& Sato, 2019; Zainudin, Mahdzan, \& Yeap, 2019). Consumer financial education is positively associated with financial capability and well-being (Xiao \& O’Neill, 2016; Xiao \& Porto, 2017). 
Consumer debt has increased greatly in recent years. In 1980, household debt service payments accounted for $11.7 \%$ of disposable personal income. The ratio increased from $10.4 \%$ to 13.0\% between 1993 and 2007. The ratio then declined substantially during the recession, falling to about 10.0\% by the end of 2015 (Board of Governors of the Federal Reserve System, 2018). Demographic shifts can explain part of the debt increase (Dynan \& Kohn, 2007). Because of the improvements in credit-scoring technology and risk-based pricing of credit card debt, the proportion of families, particularly lower-income families, that have a credit card has increased (Johnson, 2005).

Different types of debts have different effects on family economic well-being. Debt can be categorized as secured or unsecured (Garman \& Forgue, 2006). Mortgage and vehicle loans are secured debts. If consumers default on payments, institutions that issue mortgages would foreclose on the property and vehicle loan lenders would repossess the vehicle. Credit card debt, purchase loans, and educational loans are unsecured debts with no underlying assets to repossess when payments are missed. These debts are also treated differently in bankruptcy (Pace \& Lown, 2016). For example, when individuals file for bankruptcy, credit card debt may be discharged but education loans would not. Different types of debts also have different tax consequences. Mortgage and education loan interest can be deducted in income tax returns, but interests paid on other debts cannot. Research showed that higher mortgage balances increased the likelihood of dismissal and higher levels of unsecured debts were associated with discharge in consumer bankruptcy (Evans, \& Lown, 2008).

Debt can also affect family well-being in noneconomic aspects. Research indicates that short-term debts may have an adverse influence on psychological well-being, particularly for those who are less educated, approaching retirement age, or single (Berger, Collins, \& Cuesta, 
2016). Debt may affect the quality of marriages, although the evidence is mixed (Chang \& Lee, 2006; Dew, 2007; 2008).

\section{Family Structure}

This study defines "family" as used by the Federal Reserve Staff, who produce a triennial Survey of Consumer Finances, which is different from the family definition used by other government studies. Based on this definition, a family refers to "the economically dominant single person or couple (whether married or living together as partners) and all other persons in the household who are financially interdependent with that economically dominant person or couple" (Bricker et al., 2017, p.32).

Over the last several decades, family structures have changed dramatically and nontraditional family structures have become common. In $2010-14,70 \%$ of women aged 19-44 cohabited with their first husband, compared to 40\% in 1980-84 (Hemez \& Manning, 2017). Single-headed families are also more common now than several decades ago. For example, in 1969 the most common family type was married couples with children (67\% of families). However, this percentage decreased to $46 \%$ in 2016. During the same period, single females increased from $4 \%$ to $9 \%$, single mothers with children increased from $8 \%$ to $13 \%$, single males increased from $3 \%$ to $8 \%$, and single fathers with children increased from $2 \%$ to $4 \%$ (Cancian \& Reed, 2009). From 1970 to 2015, the percentage of married couples with children decreased from $87.7 \%$ to $64.7 \%$, single mothers with children increased from $8.0 \%$ to $23.1 \%$, and single fathers with children increased slightly from $3.2 \%$ to $3.9 \%$ (Child Trends, 2015).

\section{Debt and Family Structure}

Previous research on family debt by family structures is limited. Family debt patterns and trends are reported in Federal Reserve Board staff papers before 2013 (Aizcorbe, Kennickell, \& 
Moore, 2003; Bricker et al. 2012; Bucks, Kennickell, \& Moore, 2006; Bucks et al. 2009). In these studies, five types of family structures constructed by marital status, age, and presence of children have been used to examine the ownership and levels of several major types of debts but not debt burdens. Other research used variables related to family structure separately, such as marital status, gender, and presence of children. Results related to family structure were indirect and/or not presented or discussed. Marital status may be associated with debt status. Compared with married couples and single females, single males were more likely to have debt. In addition, single females tended to have a lower level of debt than single males (Lyons, 2003). Delinquent debt behavior may be associated with demographic characteristics such as marital status, age, and number of children (Canner \& Luckett, 1990).

Mortgage related financial distress may be associated with family structure. Using data from the 1999-2009 Panel Study of Income Dynamics (PSID), Stafford and Gouskova (2010) studied factors affecting mortgage borrowing behaviors. Female-headed families and families with a larger size were found to be more likely than others to fall behind on mortgage payments. Installment loans and credit card debts were associated with family structure and related variables. Compared with young singles, three types of families (empty nests, solitary families, and single parents) were more likely to borrow using installment loans. In addition, single parents tended to borrow more than all other types of families except for those recently married (Baek \& Hong, 2004). Married families tended to have higher levels of installment loans and credit card debts than single families (Chien \& DeVaney, 2001).

Money management patterns may be different for cohabiting families than for married families. A qualitative research study showed that finances were one primary reason for cohabitation (Sassler, 2004). Another qualitative study on cohabiters in the working and lower 
middle classes found that cohabiters typically perceived that financial issues were important in a marriage. Cohabiters believed marriage should occur once something had changed, in this case, their financial status (Smock, Manning, \& Porter, 2005). Several studies examined income pooling of cohabiting families. Using the 1994 International Social Survey Program data, Heimdal and Houseknecht (2003) found that cohabiters in Sweden were 2.4 times more likely than married couples to keep money separate, and were 3.6 times more likely to keep money separate in the U.S., when other factors were controlled. Using two national data sets, Winkler (1997) found that cohabiters as a group, did not pool all incomes. However, cohabiters in longerterm relationships and those who had a biological child together, might pool their incomes together. Kenney (2004) used data from the Fragile Families and Child Wellbeing Study and found that married families were more likely to pool incomes while cohabiting families were more likely to keep money separate but split expenses for family and children equally. Using the same data set, Kenney (2004) found that cohabiting couples were more likely to use a separate income system than using an income-pooling system.

Compared to married families, cohabiting families may have different spending and borrowing behaviors. Using data from the Consumer Expenditure Survey (CES), Deleire and Kalil (2005) found that compared to married families with children, cohabiting families with children spent a greater amount on alcohol and tobacco and a smaller amount on education. Cohabiting-parent families also differed in their spending patterns from divorced single-parent families and never-married single-parent families. Using data from the 1998 CES, Treas and Ruijter (2008) found differences between cohabitation and married regarding housework outsourcing. For example, the earnings of married men were more strongly linked to expenditures on female tasks (e.g. laundry, housekeeping, meals out) than were the earnings of 
cohabiting men. Painter and Vespa (2012) documented the financial advantages of cohabiting before marriage. Their study showed that spousal cohabiters began marriage with more debt than those who marry immediately, but they paid down their debt faster and generated greater home equity over time, thereby accumulating more wealth than those who married immediately. Cohabiters were intertwining credit histories and bank accounts, and acquiring assets such as purchasing homes together (Addo, 2017).

Single-mother and single-father families may have different patterns of debt behaviors. Research using data from the 1993 PSID found that controlling for the effects of education and other factors, single fathers fared better economically than single mothers (Zhan \& Pandey, 2004). Therefore, single-father families may be more likely than single-mother families to have debts with minimum asset requirements such as mortgages.

Families with children may demand different types of debts than those without children. Because many families with children are concerned about their children's education, they may be more likely to have education loans. Student loan debt is unique from other forms of debts in that it is an investment in human capital and associated with a steeper earning path that would result in greater satisfaction overall (Robb, Chatterjee, Porto, \& Cude, 2018). Homeownership is a major reason for families with children to have mortgage debt compared to their childless counterparts, which is similar to the situation where families with or without children have different saving motives (Yao, Xiao, \& Liao, 2015). Previous research showed that debt delinquency patterns varied with family lifecycle stages that formed by age, marital status, presence of children, and age of children (Xiao \& Yao, 2014).

The literature review revealed three limitations of existent research on debts by family structure. First, research on family finance, especially family debt, by family structure is limited 
and existing studies in this area are incomplete in terms of types of debts examined. Second, family structures used in previous research are not comprehensive and many previous studies do not include this variable. Third, only limited research by Federal Reserve Board staff (e.g., Bucks et al., 2009) has examined all types of debts, such as mortgage, installment loans, and credit card debt, and the family structures they use are not comprehensive in that they do not include cohabiting, single-male-headed, and single-female-headed families in their analyses. Different family structures may have different needs for different types of debts. As such, they may also face different levels of financial difficulties. This study attempts to fill these research gaps by examining debt behavioral patterns in five types of debts by eight family structures.

\section{Hypothesis Development}

Based on traditional economic theories such as the permanent income hypothesis (Friedman, 1957) and lifecycle hypothesis (Modigliani, 1986), consumers attempt to smooth their consumption by trading off resources over their lifecycle stages. For example, they save for their retirement during the earning years of their lifecycle. These theories generate more accurate predictions if family size is incorporated in the simulation model (Attanasio \& Weber, 2010). In addition, under these theories, family compositions (marital status and presence of children) may also affect borrowing behaviors (Browning and Crossley, 2001). A more recent behavioral lifecycle model, the hyperbolic model, takes debt into consideration and does simulations for debt patterns over the lifecycle. Under the hyperbolic model, consumers are more likely to take on debt during each state of the lifecycle than the traditional theories predict (Angeletos et al., 2001). However, these theories do not address how debts and burdens differ in various family structures. 
Based on the theories and empirical research reviewed before, for the purpose of hypothesis development, we make following assumptions. We assume that family borrowing is motivated by desires to smooth consumption and debt demand is determined by family size (Attanasio \& Weber, 2010). We also assume that there are no gender differences in demand for debt. Given resources, families with different structures have different levels of demands for borrowing. Thus, a family with children should demand more types of debts compared to a family without children. A married family should demand more debts compared to a single person. According to the literature (see the literature review section), a cohabiting family is usually a transition between an unmarried family to a married family and the resource level is lower than a married family but higher than an unmarried single. Therefore, their level of debt demand should be in the middle of the two types. For example, compared to a married family with children, debt demand for a cohabiting family with children is lower than the married with children family but higher than a single with children (single father or single mother). Based on these discussions, we propose following hypotheses:

H1: Married families with children are most likely to have a) any debt, and b) any specific type of debt.

H2: Singles (both males and females) without children are least likely to have a) any debt, and b) any specific type of debt.

H3: For cohabiting families, likelihoods of having a) any debt, and b) any specific type of debt are between their single and married counterparts.

Furthermore, research shows that debt burdens are associated with family resource levels (Getter, 2003; McCloud \& Dwyer, 2011). If a family has adequate resources, it does not need to borrow. If a family has trouble repaying debt, it may be due to lack of resources. Families with 
different structures may be different in demand for total debt and various types of debts as discussed before. Thus, debt default risk may be mainly associated with having debt. If a family is more likely to have a debt, it may also be more likely to bear debt burdens. Following this logic and based on H1-H3, we propose following hypotheses:

H4: Married families with children are most likely to have debt burdens.

H5: Singles (both males and females) are least likely to have debt burdens.

H6: Likelihoods of having debt burdens among cohabiting families are between their married and single counterparts.

\section{Method}

Data

This study used data from the 2016 Survey of Consumer Finances (SCF). The SCF is a triennial survey sponsored by the Federal Reserve Board in cooperation with the Statistics of Income Division of the Internal Revenue Service. The survey provides information on family financial characteristics such as income, pensions, assets, and debts as well as information about family demographic characteristics and their perceptions (Bricker et al. 2017).

The SCF combines two techniques for random sampling that address issues relevant to the full distribution of wealth, such as a higher rate of nonresponse among these households (Kennickell, 2008). First, a geographically-based random sample is selected to provide good coverage of characteristics that are broadly distributed in the population, such as homeownership. Second, a supplemental sample, called the "list sample," is selected to oversample households that are likely to be relatively wealthy. We use weights provided by the SCF in the descriptive analysis to combine the two samples and adjust for systematic differences in response rates. 
In the SCF, the "head" of the family was designated to be either the male in a mixed-sex couple family or the older individual in a same-sex couple family, regardless of who was the respondent. When the respondent was someone other than the head, all data for these two individuals were swapped so that demographic, employment, and perception variables always represent information of the head of the family. The total number of families interviewed were 6,248 .

Variables

Two types of debt variables were used: debt type and debt burden. Five debt types were included: if holding mortgage, credit card, education, vehicle, and other loans. An additional variable was used to measure any debt if the respondent reported having at least one of five types of debts mentioned before. Based on the information provided by the Federal Reserve (Bricker et al., 2017), other loan refers to loans for major purchases. For this study, it was named purchase loan. Following previous research (Bricker et al., 2017), debt burdens included two indicators measured by dummy variables: if having a debt payment to income ratio over $40 \%$ and if debt payment being 60 or more days late.

Eight family structures with respect to marital status, gender, and child status were constructed, which included married with children, married without children, cohabiting with children, cohabiting without children, single male with children, single male without children, single female with children, and single female without children. Child status refers to a family that has a child under 18 years of age (assumed to be financially dependent) or financially supports an adult child. Among these types, 27\% were married couples with children, $20 \%$ were married couples without children, $4 \%$ were cohabiting couples with children, $5 \%$ were cohabiting couples without children, $3 \%$ were single males with children, $14 \%$ were single males 
without children, $11 \%$ were single females with children, and $16 \%$ were single females without children.

Control variables included demographic characteristics (age, level of education, health status, and race), socioeconomic characteristics (employment status, homeownership, and income) and perceptions (risk tolerance, expectation of receiving heritage, and financial planning horizon). Age was a continuous variable. Education was grouped into five levels: less than a high school diploma (reference group), high school diploma/GED, some college, bachelor's degree, and graduate or professional degree. Health status included poor (reference group), fair, good, and excellent. Race included White (reference group), Black, Hispanic, and other. Employment status included work for someone else, self-employed, retired/disabled, and other groups not working (reference group). Homeownership was binary coded as 1 for yes and 0 for no (reference group). Income was divided into four quartiles using the $1^{\text {st }}$ quartile as the reference group. Risk tolerance was grouped into no (reference group), average, and higher than average. Expectation of receiving heritage was coded as 1 for yes and 0 for no. Financial planning horizon was categorized as with next year (reference group), net few years, next 5-10 years, and longer than 10 years.

\section{Data Analyses}

In the SCFs, relatively wealthy families were oversampled. Because of this oversampling, the recommended weight (X42001) was used in the analyses to obtain unbiased estimates for the entire sample families (see Kennickell, 1999 for a detailed discussion on the weight).

The survey contains a substantial amount of missing information, the patterns of which are highly heterogeneous (Kennickell, 1998). Beginning in 1989, a multiple imputation method 
(Kennickell, 1991) was used to impute missing values and five imputations were made for every missing value. Such imputation resulted in five complete data sets for each year, called the "implicates" (Kennickell, 1998). In the multivariate analysis, we use the "repeated-imputation inference" techniques (Bricker et al. 2017) to combine all five imputation replicates.

As preliminary analyses, one-way ANOVA with post hoc tests (Tukey tests) of debt variables by family structures were conducted first. Tukey test performs pairwise multiple comparisons that test the difference between each pair of means and yields a matrix where asterisks indicate significant difference of group means. Then, to test hypotheses, multivariate logistic regressions were conducted to examine associations between debt variables and a set of independent variables including family structures and control variables.

\section{Results}

\section{Bivariate Analysis Results}

\section{Debt Type by Family Structure}

Figure 1 presents descriptive statistics of the rate of having debt by family structure and Table 1 presents ANOVA post hoc test results. Percentages of having debt varied by family structures. In $2016,90 \%$ of married couples with children had any type of debt, but only $63 \%$ of childless single males did. Married families with children were more likely than other family types to have mortgage debt. In $2016,64 \%$ of married couples with children had mortgage debt. The percentages of other types of families with mortgage debt were all below $51 \%$. For example, only $22 \%$ of single males without children had mortgage debt.

The percentages having credit card debt ranged from $34 \%$ for single males without children to $52 \%$ for married couples with children. Married couples with children and cohabiting couples without children were more likely to have vehicle loans; specifically, $49 \%$ of 
married couples with children and $43 \%$ of cohabiting couples without children had vehicle loans. Singles without children were the least likely to have vehicle loans (18\% of single females and $21 \%$ of single males).

Cohabiting couples without children were most likely to have education loans (34\%) and married couples without children and single males without children were least likely to have such loans ( $12 \%$ and $13 \%$, respectively). Cohabiting couples with children were the most likely to have purchase loans $(18 \%)$, while married couples without children families were the least likely to have these loans ( $8 \%)$.

\section{Debt Burden by Family Structure}

Figure 2 presents descriptive statistics of debt burden indicators by family structures and Table 2 presents ANOVA post hoc test results. The first debt difficulty indicator is having a debt to income ratio over $40 \%$. Based on this measure, single mother families have the highest percentage (10\%) and married without children families have the lowest percentage $(5 \%)$.

Another debt related financial difficulty indicator is being late on debt payments for 60 or more days. In 2016, two family types had the highest rates in this measure: cohabiting couples with children and single females with children (both are 11\%), while again married without children families had the lowest rate (3\%).

\section{Multiple Logistic Estimation Results}

\section{Debt Types by Family Structure}

To test the hypotheses and check the robustness of the bivariate analysis results, multivariate logistic regressions were conducted where family resource and other demographic variables were controlled. Table 3 presents results of debt types regressed on family structures and control variables. The results show that married with children families were more likely than 
six other family types to have mortgages, more likely than five other types to have any debt and/or vehicle loans, more likely than four other types to have credit card debt, more likely than three other types to have education loans, and more likely than one other type to have purchase loans, partially supporting H1a and H1b.

Single males without children were least likely to have any debt (odds ratio=.335), but single females without children's odd ratio was higher than married childless families, which partially support H2a. In terms of specific debt types, single males without children had the lowest odds ratios for a mortgage, vehicle, education, and purchase loans, while single females have the lowest odds ratio only for vehicle loans, which partially supports $\mathrm{H} 2 \mathrm{~b}$.

Compared to families with children, the likelihood of having any debt for cohabiting families was in between their married and single headed family counterparts, which is consistent with H3a. However, patterns of families without children were not consistent with H3a. In terms of specific debt type, no clear patterns were shown, not supporting H3b.

Several demographic characteristics were related to having debt. Taking "any debt" as an example, age was negatively associated with having debt. Family heads who had college education or above and who were currently working were more likely to have debt. Additionally, Blacks had a greater probability of having debt than Whites. Family heads' perception of their financial planning horizon was also significantly related to having debt. Having a horizon of 5 years or longer had a negative effect on having debt when compared to those with a shorter horizon. Interestingly, families whose income lied in the $3^{\text {rd }}$ quartile had a higher probability of having debt than those in other quartiles.

Debt Burden by Family Structure 
Table 4 shows factors including family type and control variables associated with the debt burden variables. After several socioeconomic variables were controlled, no difference was found among family structures in terms of having the debt-to-income ratio over $40 \%$. For another financial difficulty indicator, being late for debt payment for 60 or more days, married with children families were more likely than three other types of families (childless married couples, single males, and single females) to be in this situation, which supports H4. Only three family structures without children - single males, single females, and married families - had significantly lower odds ratios than the reference category, married with children families, which partially supports H5. Both types of cohabiting families, with and without children, do not show differences from married with children families, thus not supporting H6.

In addition, age was negatively associated with debt burden, while self-employed families were more likely to have debt burdens. Although family heads with education of at least a college degree that were not late on debt payments but had the highest probability of debt to income ratio of over $40 \%$. It is plausible that they were more likely to owe a substantial student loan than those who never went to college. Unsurprisingly, income was negatively related to debt burdens. Families with the highest income (in the $4^{\text {th }}$ quartile) were least likely to have debt burdens.

\section{Conclusions, Implications, and Limitations}

\section{Conclusions}

With data from the 2016 Survey of Consumer Finance and an innovative definition of family structure, this study has examined if there are family structure differences in debt types and burdens of American families. Besides traditional family structure categories, this study also includes nontraditional structure categories such as cohabiting couples, single mother, and single 
father families. In addition, this study has examined patterns of having five specific types of debts and two debt burden indicators. These are unique contributions to the research literature.

Having debt can be considered as credit access for families. From the perspective of consumers, more borrowing sources mean more credit access that can help improve consumer economic well-being. Our results show that families with or without children, married vs cohabiting vs single headed families, and single female vs single male headed families are different in terms of having debt. Overall, married with children families are more likely than some other family types to have any debt and many specific types of debts. The findings also show that nontraditional family types such as cohabiting families and single headed with children families are different in terms of having some specific types of debts.

Two debt related indicators are used to measure financial difficulties, having a debt-toincome ratio over $40 \%$ and being late in debt payment for 60 or more days. Multivariate analysis results show that married with children families are more likely than childless couples, single males and single females to be late in debt payments for 60 or more days. No family structure differences are found in the other debt difficulty indicators, having the debt to income ratio over $40 \%$. These results suggest that socioeconomic variables have better explaining powers than family structure measures to explain family financial difficulties. Among two indicators that show financial difficulties, the family structure variable has a better explaining power for the being late in debt payment for 60 or more days than the debt-to-income ratio over $40 \%$ measure.

\section{Managerial and Theoretical Implications}

Our findings are informative for business practitioners, policy makers, and consumer educators. When banks and other consumer loan lenders issue loans to their customers, they may use the findings to better understand loan demands of various family structures and target them 
with effective marketing strategies. The results show that married with children families are most likely to borrow any loan and many specific types of loans, while single males without children are least likely to do so in most cases. A comparison of various loan types shows that some types have many family structure differences (mortgage, credit card, and vehicle loans) while others have fewer differences (education and purchase loans). These findings can be used to offer differentiated or undifferentiated marketing strategies when different loan products are offered.

The results also provide helpful information for loan service professionals to identify risk factors based on family structures. Our study shows that among two debt difficulty factors, being late for debt payment for 60 or more days is a better indicator than the debt to income ratio over $40 \%$ when family structure is used to predict debt difficulties. For the second indicator, all family structures can be categorized into two broad groups: 1) childless married, single males and single females and 2) all other family structures. Basically, the first group is less likely to default on debt payments than the second group, which makes the second factor a straightforward and easy indicator for risk management when loan products are offered to consumers with various family structures.

When making consumer economic policies, policy makers should consider differences in debt types and burdens of families with various structures. For example, according to the current income tax laws, married couples and cohabiting couples are treated differently with respect to income tax obligations. Married families can include the interest and points paid for the mortgage in their itemized deductions. However, this benefit is different for cohabiting families. This discriminative policy deserves policy makers' attention. Furthermore, when consumer credit protection laws are considered, special attention should be paid to certain types of families that are at greater risks of debt delinquency, such as married with children families. 
Consumer educators can incorporate relevant findings of this study to consumer financial education to improve consumers' knowledge about debt and skills needed to manage debt. Moreover, these education programs should be tailored to meet specific needs of various family structures. For example, different education materials should be designed for families that are more likely to have certain types of debts. Educators may tailor course information to meet the needs of different types of families in terms of debt types. Results of this study show that married with children families are not only more likely to have almost all types of debts, but also more likely to experience debt related difficulties. Educators who work with this type of family should provide them with appropriate information on debt control strategies. Educators also need to know that to help families with financial difficulties, being late in debt payment for 60 or more days is a better indicator than the measure of having debt-to-income ratio over $40 \%$ if they are interested in identifying which families experiencing debt related financial difficulties. Educators may deliver tailored information to families with debt related financial difficulties compared to families without major debt problems in consumer financial education.

Results of this study also have theoretical implications when relevant theories on the relationship between family structure and debt status are developed. When this study was conducted, we reviewed theories relevant to consumer debt behavior. Traditional lifecycle theory and behavioral lifecycle theory did not address debt issue explicitly. Some researchers incorporated family size and marital status into the analyses or simulations, but no theoretical frameworks were found to address the relationship between family structures and debt behavior. To better understand the family structure influences on having debt and debt burden, proper theoretical framework should be developed in future research. Findings of this study could provide helpful information toward building relevant theories on this topic. 


\section{Limitations and Future Research}

Although this study is more comprehensive than previous research regarding family structure, it is still limited to information available from the data. For example, information about same-sex families is available but the sample size is too small for meaningful analyses. There were only 63 same-sex couples in the sample, among which 27 are married and 36 are cohabiting. To address this topic, data on same-sex couples should be collected and utilized. Second, this study focused on family structure differences in debt types and burdens at one time point. It would be interesting to examine the effect of family structure changes on debt type and burden from a dynamic perspective. This topic could be examined with appropriate panel data in future research.

\section{Ethical Approval}

Data used in this study is a secondary data set sponsored by the U.S. Federal Reserve Board, which was used by many researchers around the world. The authors of this article do not work with human participants of the data set directly.

\section{References}

Addo, F. R. (2017). Financial integration and relationship transitions of young adult cohabiters. Journal of Family and Economic Issues, 38(1), 84-99.

Aizcorbe, A. M., Kennickell, A. B., \& Moore, K. B. (2003, January). Recent changes in U.S. family finances: Evidence from the 1998 and 2001 survey of consumer finances. Federal Reserve Bulletin, 1-32.

Angeletos, G., Laibson, D., Repetto, A., Tobacman, J., \& Weinberg, S. (2001). The hyperbolic consumption model: Calibration, simulation, and empirical evaluation. Journal of Economic Perspectives, 15(3), 47-68. 
Attanasio, O. P., \& Weber, G. (2010). Consumption and saving: Models of intertemporal allocation and their implications for public policy. Journal of Economic Literature, 48(3), $693-751$.

Baek, E., \& Hong, G. (2004). Effects of family life-cycle stages on consumer debts. Journal of Family and Economic Issues, 25(3), 359-385.

Berger, L. M., Collins, J. M., \& Cuesta, L. (2016). Household debt and adult depressive symptoms in the United States. Journal of Family and Economic Issues, 37(1), 42-57.

Board of Governors of the Federal Reserve System (2018), Household debt service payments as a percent of disposable personal income. Retrieved from FRED, Federal Reserve Bank of St. Louis; https://fred.stlouisfed.org/series/TDSP, February 4, 2018.

Bricker, J., Dettling, L. J., Henriques, A., Hsu, J. W., Jacobs, L., Moore, K. B., Pack, S., Sabelhaus, J., Thompson, J., \& Windle, R. A. (2017). Changes in U.S. family finances from 2013 to 2016: Evidence from the survey of consumer finances. Federal Reserve Bulletin, 103(3), 1-41.

Bricker, J., Dettling, L. J., Henriques, A., Hsu, J. W., Moore, K. B., Sabelhaus, J., Thompson, J., \& Windle, R. A. (2014). Changes in U.S. family finances from 2010 to 2013: Evidence from the survey of consumer finances. Federal Reserve Bulletin, 100(4), 1-40.

Bricker, J., Kennickell, A. B., Moore, K. B., \& Sabelhaus, J. (2012). Changes in U.S. family finances from 2007 to 2010: Evidence from the survey of consumer finances. Federal Reserve Bulletin, 100(1), 1-80.

Browning, M. and Crossley, T. (2001), “The life-cycle model of consumption and saving”, The Journal of Economic Perspectives, Vol. 15 No. 3, pp. 3-22. 
Bryant, W. K., \& Zick, C. D. (2006). The economic organization of the household (2 $2^{\text {nd }}$ ed.). New York: Cambridge University Press.

Bucks, B. K., Kennickell, A. B., \& Moore, K. B. (2006). Recent changes in U.S. family finances: Evidence from the 2001 and 2004 Survey of Consumer Finances. Federal Reserve Bulletin, A1-A38.

Bucks, B., Kennickell, A., Mach, T., \& Moore, K. (2009, January). Changes in U.S. family finances from 2004 to 2007: Evidence from the Survey of Consumer Finances. Federal Reserve Bulletin, 95, A1-A55.

Cancian, M., \& Reed, D. (2009). Family structure, childbearing, and parental employment: Implications for the level and trend in poverty. Focus, 26(2), 21-26. Retrieved January 23, 2011 from http://www.irp.wisc.edu/publications/focus/pdfs/foc262d.pdf

Canner, G., B., \& Luckett, C. A. (1990). Consumer debt repayment woes: Insights from a household survey. Journal of Retail Banking, 12(1), 55-62.

Chang, Y., \& Lee, K. Y. (2006). Household debt and marital instability: Evidence from the Korean Labor and Income Panel Study. Journal of Family and Economic Issues, 27(4), 675-691.

Chien, Y., \& DeVaney, S. A. (2001). The effects of credit attitude and socioeconomic factors on credit card and installment debt. Journal of Consumer Affairs, 35(1), 162-179.

Child Trends (2015). Family structure: Indicators of child and youth well-being. http://childtrends.org/wp-content/uploads/2015/03/59_Family_Structure.pdf

Deleire, T., \& Kalil, A. (2005). How do cohabiting couples with children spend their money? Journal of Marriage and Family, 67(May), 286-295. 
Dew, J. (2007). Two sides of the same coin? The differing roles of assets and consumer debt in marriage. Journal of Family \& Economic Issues, 28(1), 89-104.

Dew, J. (2008). Debt change and marital satisfaction change in recently married couples. Family Relations, 57, 60-71

Dynan, K. E. (2009). Changing household financial opportunities and economic security. Journal of Economic Perspectives, 23(4), 49-68.

Dynan, K. E., \& Kohn, D. L. (2007). The rise in U.S. household indebtedness: Causes and consequences. In C. Kent and J. Lawson (eds.). The structure and the resilience of the financial system: Proceedings of a conference, (pp. 84-113). Sydney: Reserve Bank of Australia.

Estelami, H. (2018). Incidence and magnitude of quantity surcharges and quantity discounts in online shopping. Journal of Consumer Affairs, 52(3), 517-539.

Evans, D. A., \& Lown, J. M. (2008). Predictors of chapter 13 completion rates: The role of socioeconomic variables and consumer debt type. Journal of Family and Economic Issues, 29(2), 202-218.

Friedman, M. (1957). A theory of the consumption function. Princeton and Oxford: Princeton University Press.

Garman, E. T., \& Forgue, R. E. (2006). Personal finance ( $8^{\text {th }}$ ed.). Boston: Houghton Mifflin Company.

Gerardi, K. (2010). Financial literacy and subprime mortgage delinquency: Evidence from a survey matched to administrative data. DIANE Publishing.

Getter, D. E. (2003). Contributing to the delinquency of borrowers. Journal of Consumer Affairs, $37(1), 86-100$. 
Heimdal, K. R., \& Houseknecht, S. K. (2003). Cohabiting and married couples’ income organization: Approaches in Sweden and the United States. Journal of Marriage and Family, 65(August), 525-538.

Hemez, P., \& Manning, W. D. (2017). Thirty-years of change in women's premarital cohabition experience. Family Profiles, FP-17-05. Bowling Green, OH: National Center for Familly and Marriage Research. https://www.bgsu.edu/content/dam/BGSU/college-of-arts-andsciences/NCFMR/documents/FP/hemez-manning-30-yrs-change-women-premaritalcohab-fp-17-05.pdf

Hirschl, T. A., Altobelli, J., \& Rank, M. R. (2003). Does marriage increase the odds of affluence? Exploring the life course probabilities. Journal of Marriage and Family, 65 (November), 927-938.

Johnson, K. W. (2005). Recent development in the credit card market and the financial obligations ration. Federal Reserve Bulletin (Autumn), 473-486.

Kenney, C. (2004). Cohabiting couple, filing jointly? Resource pooling and U.S. poverty policies. Family Relations, 53, 237-247.

Kennickell, A. B. (1991). Imputation of the 1989 Survey of Consumer Finances: Stochastic relaxation and multiple imputation. Proceedings of the Section on Survey Research Methods, Annual Meetings of the American Statistical Association, Atlanta, GA.

Kennickell, A. B. (1998). Multiple imputation in the Survey of Consumer Finances. Federal Reserve Board SCF Working Paper. Retrieved from http://www.federalreserve.gov/pubs/oss/oss2/method.html 
Kennickell, A. B. (1999). Revisions of the SCF weighting methodology: Accounting for race/ethnicity and homeownership. Washington, DC: Board of Governors of the Federal Reserve System. www.federalreserve.gov/pubs/oss/oss2/method.html.

Kennickell, A. B. (2008). The role of over-sampling of the wealthy in the survey of consumer finances. Irving Fisher Committee Bulletin, 28, 403-408.

Kroszner, R. S., \& Strahan, P. E. (2014). Regulation and deregulation of the US banking industry: causes, consequences, and implications for the future. In Economic Regulation and Its Reform: What Have We Learned? (pp. 485-543). University of Chicago Press.

Lander, D. A. (2016). Consumer credit regulation. In J. J. Xiao (ed.). Handbook of consumer finance research (pp.301-314). New York: Springer.

Limbu, Y. B., \& Sato, S. (2019). Credit card literacy and financial well-being of college students. The International Journal of Bank Marketing, 37(4), 991-1003. doi:http://dx.doi.org.uri.idm.oclc.org/10.1108/IJBM-04-2018-0082

Lusardi, A., \& Tufano, P. (2015). Debt literacy, financial experiences, and overindebtedness. Journal of Pension Economics \& Finance, 14(4), 332-368.

Lyons, A.C. (2003). How credit access has changed over time for U. S. households. Journal of Consumer Affairs, 37(Winter), 231-255.

McCloud, L., \& Dwyer, R. E. (2011). The fragile American: hardship and financial troubles in the 21st century. The Sociological Quarterly, 52(1), 13-35.

Modigliani, F. (1986). Life cycle, thrift, and the wealth of nations. American Economic Review, 76, 297-313.

Moore, D. L. (2003). Survey of financial literacy in Washington State: Knowledge, behavior, attitudes, and experiences. Washington State Department of Financial Institutions. 
Pace, L. N., \& Lown, J. M. (2016). Consumer bankruptcy. In J. J. Xiao (ed.). Handbook of consumer finance research (2 ${ }^{\text {nd }}$ ed.). (pp. 315-326). New York: Springer.

Painter, M. A., \& Vespa, J. (2012). The role of cohabitation in asset and debt accumulation during marriage. Journal of Family and Economic Issues, 33(4), 491-506.

Robb, C. A., Chatterjee, S., Porto, N., \& Cude, B. J. (2018). The influence of student loan debt on financial satisfaction. Journal of Family and Economic Issues, 1-23.

Ryan, A., Trumbull, G., \& Tufano, P. (2010). A brief postwar history of U. S. consumer finance. Finance Working Paper No. 11-058, Harvard Business School.

Sassler, S. (2004). The process of entering into cohabiting unions. Journal of Marriage and Family, 66(May), 491-505.

Smock, P. J., Manning, W. D., \& Porter, M. (2005). 'Everything's there except money'?: How money shapes decisions to marry among cohabitors. Journal of Marriage and Family, 67(August), 680-696.

Stafford, F. P., \& Gouskova, E. (2010). Mortgage contract decisions and mortgage distress: Family and financial life-cycle factors. Working Paper 2010-225. Retirement Research Center, University of Michigan.

Stango, V., \& Zinman, J. (2009). Exponential growth bias and household finance. The Journal of Finance, 64(6), 2807-2849.

Treas, J., \& Ruijter, E. D. (2008). Earnings and expenditures on household services in married and cohabiting unions. Journal of Marriage and Family, 70(August), 796-805.

Tufano, P. (2016). Forward. In J. J. Xiao (ed.). Handbook of consumer finance research. (2 ${ }^{\text {nd }}$ ed.) (pp. v-vii). New York: Springer. 
Winkler, A. E. (1997). Economic decision-making by cohabitors: Findings regarding income pooling. Applied Economics, 29(8), 1079-1090.

Xiao, J. J. (2015). Consumer economic wellbeing. New York: Springer.

Xiao, J. J., \& O’Neill, B. (2016). Consumer financial education and financial capability. International Journal of Consumer Studies, 40(6), 712-721.

Xiao, J. J., \& Porto, N. (2017). Financial education and financial satisfaction: Financial literacy, behavior, and capability as mediators. International Journal of Bank Marketing, 35(5), 805-817.

Xiao, J. J., \& Yao, R. (2014). Consumer debt delinquency by family lifecycle categories. International Journal of Bank Marketing, 32(1), 43-59.

Yao, R., Xiao, J. J., \& Liao, L. (2015). Effects of age on saving motives of Chinese urban consumers. Journal of Family and Economic Issues, 36(2), 224-238.

Zainudin, R., Mahdzan, N. S., \& Yeap, M. (2019). Determinants of credit card misuse among gen Y consumers in urban Malaysia. The International Journal of Bank Marketing, 37(5), 1350-1370. doi:http://dx.doi.org.uri.idm.oclc.org/10.1108/IJBM-08-2018-0215

Zhan, M., \& Pandey, S. (2004). Postsecondary education and economic well-being of single mothers and single fathers. Journal of Marriage and Family, 66(August), 661-673.

Zingales, L. (2015). Presidential address: Does finance benefit society? The Journal of Finance, 70(4), 1327-1363. 
Figure 1 Debt Type by Family Structure

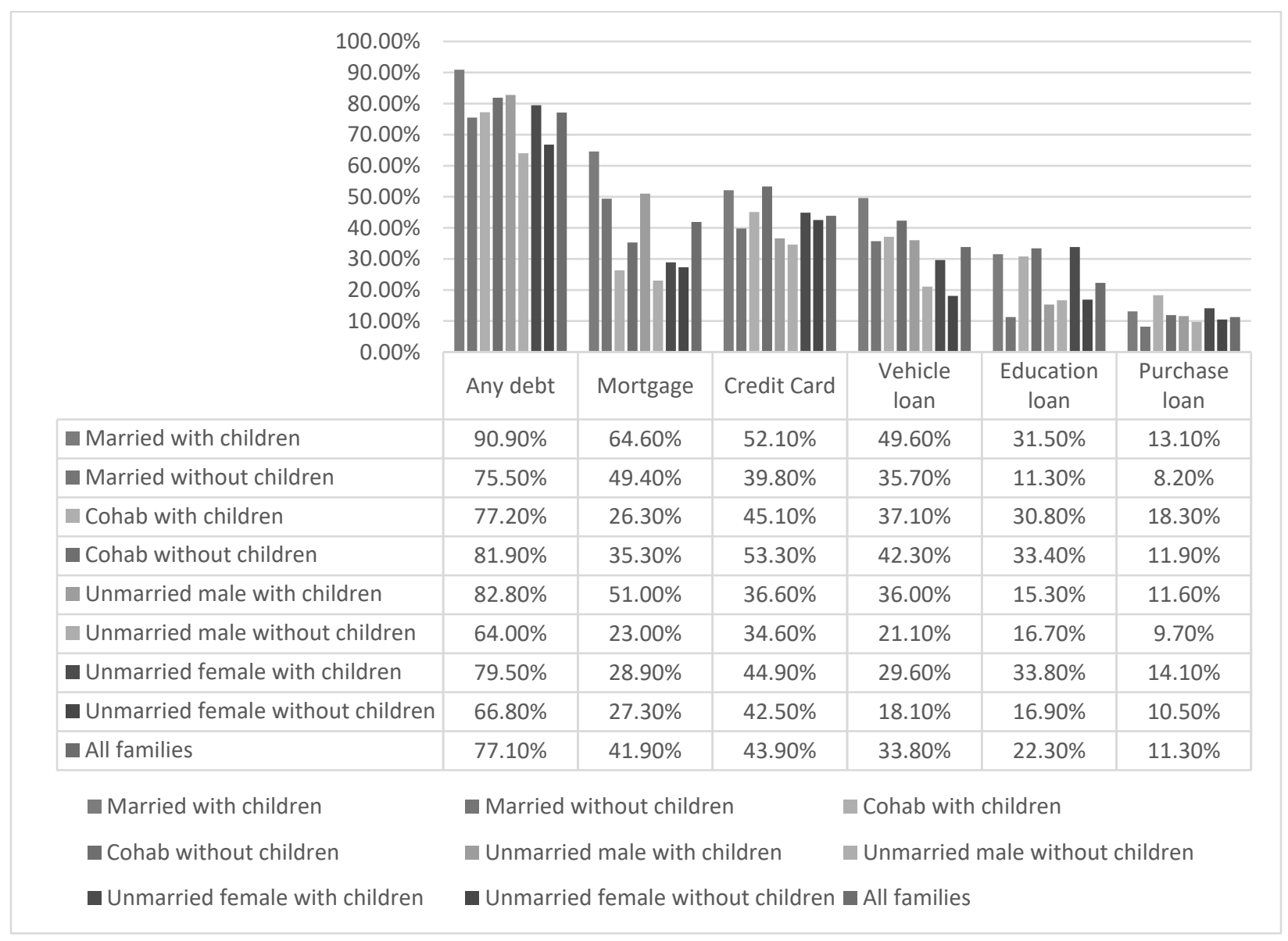


Figure 2 Debt Burden by Family Structure

\begin{tabular}{|c|c|c|}
\hline \multicolumn{3}{|l|}{12} \\
\hline \multicolumn{3}{|l|}{10} \\
\hline \multicolumn{3}{|l|}{8} \\
\hline 6 & & \\
\hline 4 & & \\
\hline 2 & & \\
\hline 0 & DI Ratior over $40 \%$ & Delinquency \\
\hline Married with children & 6.73 & 6.3 \\
\hline Married without children & 4.71 & 2.47 \\
\hline Cohab with children & 5.72 & 11.18 \\
\hline - Cohab without children & 6.32 & 6.54 \\
\hline - Unmarried male with children & 9.01 & 7.87 \\
\hline - Unmarried male without children & 7.97 & 4.74 \\
\hline Unmarried female with children & 10.34 & 11.17 \\
\hline Unmarried female without children & 8.14 & 4.43 \\
\hline All families & 7.1 & 5.82 \\
\hline Married with children & Married without children & Cohab with children \\
\hline - Cohab without children & - Unmarried male with children & Unmarried male without children \\
\hline Unmarried female with children & - Unmarried female without chi & All families \\
\hline
\end{tabular}


Table 1: One-way ANOVA Tukey Test Results of Debt by Family Type

\begin{tabular}{|c|c|c|c|c|c|c|c|c|}
\hline & $\begin{array}{l}\text { Married } \\
\text { with } \\
\text { children }\end{array}$ & $\begin{array}{l}\text { Married } \\
\text { without } \\
\text { children }\end{array}$ & $\begin{array}{l}\text { Cohab with } \\
\text { children }\end{array}$ & $\begin{array}{c}\text { Cohab } \\
\text { without } \\
\text { children }\end{array}$ & $\begin{array}{c}\text { Single male } \\
\text { with } \\
\text { children }\end{array}$ & $\begin{array}{c}\text { Single male } \\
\text { without } \\
\text { children }\end{array}$ & $\begin{array}{c}\text { Single } \\
\text { female with } \\
\text { children }\end{array}$ & $\begin{array}{l}\text { Single } \\
\text { female } \\
\text { without } \\
\text { children }\end{array}$ \\
\hline \multicolumn{9}{|c|}{ Panel A: Any debt } \\
\hline Married with children & &,$+ * * *$ &,$+ * * *$ &,$+ * * *$ &,$+ * * *$ &,$+ * * *$ &,$+ * * *$ &,$+ * * *$ \\
\hline Married without children &,$- * * *$ & & &,$- * * *$ &,$- * * *$ &,$+ * * *$ &,$- * * *$ &,$+ * * *$ \\
\hline Cohab with children &,$- * * *$ & & &,$- * *$ & &,$+ * * *$ & &,$+ * * *$ \\
\hline Cohab without children &,$- * * *$ &,$+ * * *$ &,$+ * *$ & & &,$+ * * *$ & &,$+ * * *$ \\
\hline Single male with children &,$- * * *$ &,$+ * * *$ & & & &,$+ * * *$ & &,$+ * * *$ \\
\hline Single male without children &,$- * * *$ &,$- * * *$ &,$- * * *$ &,$- * * *$ &,$- * * *$ & &,$- * * *$ &,$- * *$ \\
\hline Single female with children &,$- * * *$ &,$+ * * *$ & & & &,$+ * * *$ & &,$+ * * *$ \\
\hline Single female without children &,$- * * *$ &,$- * * *$ &,$- * * *$ &,$- * * *$ &,$- * * *$ &,$+ * *$ &,$- * * *$ & \\
\hline \multicolumn{9}{|c|}{ Panel B: Mortgage } \\
\hline Married with children & &,$+ * * *$ &,$+ * * *$ &,$+ * * *$ &,$+ * * *$ &,$+ * * *$ &,$+ * * *$ &,$+ * * *$ \\
\hline Married without children &,$- * * *$ & &,$+ * * *$ &,$+ * * *$ & &,$+ * * *$ &,$+ * * *$ &,$+ * * *$ \\
\hline Cohab with children &,$- * * *$ &,$- * * *$ & &,$- * * *$ &,$- * * *$ &,$+ * *$ & & \\
\hline Cohab without children &,$- * * *$ &,$- * * *$ &,$+ * * *$ & &,$- * * *$ &,$+ * * *$ &,$+ * * *$ &,$+ * * *$ \\
\hline Single male with children &,$- * * *$ & &,$+ * * *$ &,$+ * * *$ & &,$+ * * *$ &,$+ * * *$ &,$+ * * *$ \\
\hline Single male without children &,$- * * *$ &,$- * * *$ &,$- * *$ &,$- * * *$ &,$- * * *$ & &,$- * * *$ &,$- * * *$ \\
\hline Single female with children &,$- * * *$ &,$- * * *$ & &,$- * * *$ &,$- * * *$ &,$+ * * *$ & & \\
\hline Single female without children &,$- * * *$ &,$- * * *$ & &,$- * * *$ &,$- * * *$ &,$+ * * *$ & & \\
\hline \multicolumn{9}{|c|}{ Panel C: Credit Card } \\
\hline Married with children & &,$+ * * *$ &,$+ * * *$ & &,$+ * * *$ &,$+ * * *$ &,$+ * * *$ &,$+ * * *$ \\
\hline Married without children &,$- * * *$ & &,$- * * *$ &,$- * * *$ & &,$+ * * *$ &,$- * * *$ &,$- * *$ \\
\hline Cohab with children &,$- * * *$ &,$+ * * *$ & &,$- * * *$ &,$+ *$ &,$+ * * *$ & & \\
\hline Cohab without children & &,$+ * * *$ &,$+ * * *$ & &,$+ * * *$ &,$+ * * *$ &,$+ * * *$ &,$+ * * *$ \\
\hline Single male with children &,$- * * *$ & &,$- *$ &,$- * * *$ & & &,$- * *$ & \\
\hline Single male without children &,$- * * *$ &,$- * * *$ &,$- * * *$ &,$- * * *$ & & &,$- * * *$ &,$- * * *$ \\
\hline Single female with children &,$- * * *$ &,$+ * * *$ & &,$- * * *$ &,$+ * *$ &,$+ * * *$ & & \\
\hline Single female without children &,$- * * *$ &,$+ * *$ & &,$- * * *$ & &,$+ * * *$ & & \\
\hline
\end{tabular}




\begin{tabular}{|c|c|c|c|c|c|c|c|c|}
\hline & $\begin{array}{l}\text { Married } \\
\text { with } \\
\text { children }\end{array}$ & $\begin{array}{l}\text { Married } \\
\text { without } \\
\text { children }\end{array}$ & $\begin{array}{l}\text { Cohab with } \\
\text { children }\end{array}$ & $\begin{array}{c}\text { Cohab } \\
\text { without } \\
\text { children }\end{array}$ & $\begin{array}{c}\text { Single male } \\
\text { with } \\
\text { children }\end{array}$ & $\begin{array}{c}\text { Single male } \\
\text { without } \\
\text { children }\end{array}$ & $\begin{array}{c}\text { Single } \\
\text { female with } \\
\text { children }\end{array}$ & $\begin{array}{c}\text { Single } \\
\text { female } \\
\text { without } \\
\text { children }\end{array}$ \\
\hline \multicolumn{9}{|c|}{ Panel D: Vehicle Loan } \\
\hline Married with children & &,$+ * * *$ &,$+ * * *$ &,$+ * * *$ &,$+ * * *$ &,$+ * * *$ &,$+ * * *$ &,$+ * * *$ \\
\hline Married without children &,$- * * *$ & & &,$- * * *$ & &,$+ * * *$ &,$+ * * *$ &,$+ * * *$ \\
\hline Cohab with children &,$- * * *$ & & &,$- * *$ & &,$+ * * *$ &,$+ * * *$ &,$+ * * *$ \\
\hline Cohab without children &,$- * * *$ &,$+ * * *$ &,$+ * *$ & &,$+ * * *$ &,$+ * * *$ &,$+ * * *$ &,$+ * * *$ \\
\hline Single male with children &,$- * * *$ & & &,$- * * *$ & &,$+ * * *$ & &,$+ * * *$ \\
\hline Single male without children &,$- * * *$ &,$- * * *$ &,$- * * *$ &,$- * * *$ &,$- * * *$ & &,$- * * *$ &,$+ *$ \\
\hline Single female with children &,$- * * *$ &,$- * * *$ &,$- * * *$ &,$- * * *$ & &,$+ * * *$ & &,$+ * * *$ \\
\hline Single female without children &,$- * * *$ &,$- * * *$ &,$- * * *$ &,$- * * *$ &,$- * * *$ &,$-^{*}$ &,$- * * *$ & \\
\hline \multicolumn{9}{|c|}{ Panel E: Education Loan } \\
\hline Married with children & &,$+ * * *$ & &,$- * * *$ &,$+ * * *$ &,$+ * * *$ & &,$+ * * *$ \\
\hline Married without children &,$- * * *$ & &,$- * * *$ &,$- * * *$ & &,$- * * *$ &,$- * * *$ &,$- * * *$ \\
\hline Cohab with children & &,$+ * * *$ & &,$-^{*}$ &,$+ * * *$ &,$+ * * *$ & &,$+ * * *$ \\
\hline Cohab without children &,$+ * * *$ &,$+ * * *$ &,$+ *$ & &,$+ * * *$ &,$+ * * *$ & &,$+ * * *$ \\
\hline Single male with children &,$- * * *$ & &,$- * * *$ &,$- * * *$ & & &,$- * * *$ & \\
\hline Single male without children &,$- * * *$ &,$+ * * *$ &,$- * * *$ &,$- * * *$ & & &,$- * * *$ & \\
\hline Single female with children & &,$+ * * *$ & & &,$+ * * *$ &,$+ * * *$ & &,$+ * * *$ \\
\hline Single female without children &,$- * * *$ &,$+ * * *$ &,$- * * *$ &,$- * * *$ & & &,$- * * *$ & \\
\hline \multicolumn{9}{|c|}{ Panel F: Purchase Loan } \\
\hline Married with children & &,$+ * * *$ &,$- * * *$ & & &,$+ * * *$ & &,$+ *$ \\
\hline Married without children &,$- * * *$ & &,$- * * *$ &,$- * *$ & & &,$- * * *$ &,$- * *$ \\
\hline Cohab with children &,$+ * * *$ &,$+ * * *$ & &,$+ * * *$ &,$+ * * *$ &,$+ * * *$ &,$+ * * *$ &,$+ * * *$ \\
\hline Cohab without children & &,$+ * *$ &,$- * * *$ & & & & & \\
\hline Single male with children & & &,$- * * *$ & & & & & \\
\hline Single male without children &,$- * * *$ & &,$- * * *$ & & & &,$- * * *$ & \\
\hline Single female with children & &,$+ * * *$ &,$- * * *$ & & &,$+ * * *$ & &,$+ * * *$ \\
\hline Single female without children &,$- *$ &,$+ * *$ &,$- * * *$ & & 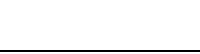 & &,$- * * *$ & \\
\hline
\end{tabular}


Table 2: One-way ANOVA Tukey Test Results of Debt Burden by Family Type

\begin{tabular}{|c|c|c|c|c|c|c|c|c|}
\hline & $\begin{array}{l}\text { Married } \\
\text { with } \\
\text { children }\end{array}$ & $\begin{array}{l}\text { Married } \\
\text { without } \\
\text { children }\end{array}$ & $\begin{array}{l}\text { Cohab with } \\
\text { children }\end{array}$ & $\begin{array}{l}\text { Cohab } \\
\text { without } \\
\text { children }\end{array}$ & $\begin{array}{l}\text { Single male } \\
\text { with } \\
\text { children }\end{array}$ & $\begin{array}{c}\text { Single male } \\
\text { without } \\
\text { children }\end{array}$ & $\begin{array}{l}\text { Single } \\
\text { female with } \\
\text { children }\end{array}$ & $\begin{array}{l}\text { Single } \\
\text { female } \\
\text { without } \\
\text { children }\end{array}$ \\
\hline \multicolumn{9}{|c|}{ Panel A: Debt to Income Ratio over $40 \%$} \\
\hline Married with children & &,$+ * * *$ & & & & &,$- * * *$ &,$-^{*}$ \\
\hline Married without children &,$- * * *$ & & & &,$- * * *$ &,$- * * *$ &,$- * * *$ &,$- * * *$ \\
\hline Cohab with children & & & & & & &,$- * * *$ &,$-{ }^{*}$ \\
\hline Cohab without children & & & & & & &,$- * * *$ & \\
\hline Single male with children & &,$+ * * *$ & & & & & & \\
\hline Single male without children & &,$+ * * *$ & & & & &,$-^{* *}$ & \\
\hline Single female with children &,$+ * * *$ &,$+ * * *$ &,$+ * * *$ &,$+ * * *$ & &,$+ * *$ & &,$+ * *$ \\
\hline Single female without children &,$+ *$ &,$+ * * *$ &,$+ *$ & & & &,$- * *$ & \\
\hline \multicolumn{9}{|c|}{ Panel B: Debt Payment being 60 or more Days Late } \\
\hline Married with children & &,$+ * * *$ &,$- * * *$ & & &,$+ * *$ &,$- * * *$ &,$+ * * *$ \\
\hline Married without children &,$- * * *$ & &,$- * * *$ &,$- * * *$ &,$- * * *$ &,$- * * *$ &,$- * * *$ &,$- * * *$ \\
\hline Cohab with children &,$+ * * *$ &,$+ * * *$ & &,$+ * * *$ &,$+ *$ &,$+ * * *$ & &,$+ * * *$ \\
\hline Cohab without children & &,$+ * * *$ &,$- * * *$ & & & &,$- * * *$ &,$+ *$ \\
\hline Single male with children & &,$+ * * *$ &,$- *$ & & &,$+ * *$ &,$- * *$ &,$+ * *$ \\
\hline Single male without children & $-{ }^{* *}$ &,$+ * * *$ &,$- * * *$ & &,$- * *$ & &,$- * * *$ & \\
\hline Single female with children &,$+ * * *$ &,$+ * * *$ & &,$+ * * *$ &,$+ * *$ &,$+ * * *$ & &,$+ * * *$ \\
\hline Single female without children &,$- * * *$ &,$+ * * *$ &,$- * * *$ &,$-^{*}$ &,$- * *$ & &,$- * * *$ & \\
\hline
\end{tabular}


Table 3: Binary Logistic Analysis of Debt (Reference Category= No)

\begin{tabular}{|c|c|c|c|c|c|c|c|c|c|c|c|c|}
\hline \multirow[b]{2}{*}{ Parameter } & \multicolumn{2}{|c|}{ Any Debt } & \multicolumn{2}{|c|}{ Mortgage } & \multicolumn{2}{|c|}{ Credit Card } & \multicolumn{2}{|c|}{ Vehicle Loan } & \multicolumn{2}{|c|}{ Education Loan } & \multicolumn{2}{|c|}{ Purchase Loan } \\
\hline & Coef. & $\begin{array}{l}\text { Odds } \\
\text { ratio }\end{array}$ & Coef. & $\begin{array}{l}\text { Odds } \\
\text { ratio }\end{array}$ & Coef. & $\begin{array}{l}\text { Odds } \\
\text { ratio }\end{array}$ & Coef. & $\begin{array}{l}\text { Odds } \\
\text { ratio }\end{array}$ & Coef. & $\begin{array}{l}\text { Odds } \\
\text { ratio }\end{array}$ & Coef. & $\begin{array}{l}\text { Odds } \\
\text { ratio }\end{array}$ \\
\hline Intercept & $1.786^{* * *}$ & & $1.533^{* * *}$ & & $-1.170 * * *$ & & $-0.424 *$ & & 0.531 & & -0.222 & \\
\hline Age & $-0.031 * * *$ & 0.969 & $0.010 * * *$ & 1.010 & $-0.007 *$ & 0.993 & $-0.021 * * *$ & 0.979 & $-0.062 * * *$ & 0.940 & $-0.020 * * *$ & 0.980 \\
\hline \multicolumn{13}{|c|}{ Level of education (reference category= less than a high school diploma) } \\
\hline High school dip./GED & -0.058 & 0.944 & 0.218 & 1.244 & 0.115 & 1.122 & -0.046 & 0.955 & $0.915 * * *$ & 2.497 & -0.007 & 0.993 \\
\hline Some college & $0.608 * * *$ & 1.837 & $0.390^{*}$ & 1.478 & $0.403^{* *}$ & 1.496 & 0.182 & 1.200 & $2.266^{* * *}$ & 9.641 & 0.191 & 1.210 \\
\hline Bachelor's degree & $0.515^{* * *}$ & 1.674 & $0.462^{* *}$ & 1.587 & 0.081 & 1.084 & -0.148 & 0.862 & $2.529 * * *$ & 12.541 & -0.118 & 0.889 \\
\hline $\begin{array}{l}\text { Graduate/professional } \\
\text { degree }\end{array}$ & $0.330^{*}$ & 1.391 & $0.382 *$ & 1.465 & -0.265 & 0.767 & -0.274 & 0.760 & $2.947 * * *$ & 19.049 & 0.044 & 1.045 \\
\hline \multicolumn{13}{|c|}{ Employment status (reference category= other groups not working) } \\
\hline Work for someone else & $0.837 * * *$ & 2.309 & $0.251^{*}$ & 1.285 & $0.678 * * *$ & 1.970 & $0.629 * * *$ & 1.876 & 0.234 & 1.264 & 0.207 & 1.230 \\
\hline Self-employed & $0.622 * * *$ & 1.863 & 0.159 & 1.172 & $0.573 * * *$ & 1.774 & 0.226 & 1.254 & -0.072 & 0.931 & 0.082 & 1.085 \\
\hline Retired/disabled & 0.082 & 1.085 & $-0.378^{*}$ & 0.685 & 0.124 & 1.132 & 0.083 & 1.087 & -0.310 & 0.733 & -0.023 & 0.977 \\
\hline \multicolumn{13}{|c|}{ Risk tolerance $($ reference category $=$ no) } \\
\hline Higher than average & -0.113 & 0.893 & 0.013 & 1.013 & -0.163 & 0.850 & $-0.244 *$ & 0.783 & -0.120 & 0.887 & -0.138 & 0.871 \\
\hline Average & 0.009 & 1.009 & -0.019 & 0.981 & -0.029 & 0.971 & 0.005 & 1.005 & 0.057 & 1.059 & -0.096 & 0.908 \\
\hline \multicolumn{13}{|c|}{ Health status(reference category $=$ poor $)$} \\
\hline Excellent & -0.315 & 0.730 & -0.098 & 0.906 & -0.044 & 0.957 & -0.244 & 0.783 & $-0.756 * * *$ & 0.470 & $-0.850 * * *$ & 0.427 \\
\hline Good & -0.111 & 0.895 & -0.053 & 0.948 & 0.153 & 1.165 & -0.155 & 0.856 & $-0.672 * *$ & 0.511 & $-0.631^{* *}$ & 0.532 \\
\hline Fair & -0.169 & 0.845 & -0.192 & 0.825 & 0.081 & 1.084 & -0.345 & 0.708 & $-0.562 *$ & 0.570 & -0.304 & 0.738 \\
\hline Expected to receive heritage & -0.016 & 0.984 & -0.006 & 0.994 & 0.026 & 1.026 & -0.071 & 0.931 & -0.051 & 0.950 & -0.088 & 0.916 \\
\hline \multicolumn{13}{|c|}{ Financial planning horizon (reference category= within next year) } \\
\hline Next few years & -0.028 & 0.972 & $0.185^{*}$ & 1.203 & 0.027 & 1.027 & -0.041 & 0.960 & $-0.209^{*}$ & 0.811 & -0.092 & 0.912 \\
\hline Next $5-10$ years & $-0.311 * *$ & 0.733 & $0.214^{*}$ & 1.238 & -0.295 & 0.745 & -0.080 & 0.923 & $-0.385 * * *$ & 0.680 & $-0.341^{*}$ & 0.711 \\
\hline Longer than 10 years & $-0.477 * * *$ & 0.621 & $0.381 * * *$ & 1.464 & $-0.446^{* * *}$ & 0.640 & -0.207 & 0.813 & $-0.384 * *$ & 0.681 & -0.284 & 0.753 \\
\hline \multicolumn{13}{|c|}{ Race (reference category $=$ white $)$} \\
\hline Black & $0.289 *$ & 1.335 & -0.185 & 0.831 & $0.357 * * *$ & 1.429 & $0.223 *$ & 1.250 & $0.537 * * *$ & 1.711 & -0.181 & 0.834 \\
\hline Hispanic & -0.092 & 0.912 & $-0.307^{*}$ & 0.736 & $0.364 * * *$ & 1.439 & -0.102 & 0.903 & -0.184 & 0.832 & -0.276 & 0.759 \\
\hline Other & -0.240 & 0.787 & $-0.357^{*}$ & 0.700 & -0.002 & 0.998 & -0.198 & 0.820 & $-0.435^{*}$ & 0.647 & -0.495 & 0.610 \\
\hline Homeownership & $1.162 * * *$ & 3.196 & - & - & $0.399 * * *$ & 1.490 & $0.421 * * *$ & 1.523 & $-0.241 *$ & 0.786 & $0.127^{*}$ & 1.135 \\
\hline \multicolumn{13}{|c|}{ Family type (reference category= married with children) } \\
\hline Married without children & $-0.712 * * *$ & 0.491 & $-0.636^{* * *}$ & 0.530 & $-0.336^{* * *}$ & 0.715 & $-0.233^{*}$ & 0.792 & $-0.482 * * *$ & 0.618 & -0.259 & 0.772 \\
\hline Cohabit with children & $-0.839 * * *$ & 0.432 & $-1.162 * * *$ & 0.313 & $-0.352 *$ & 0.703 & $-0.464 * *$ & 0.629 & -0.256 & 0.774 & 0.103 & 1.108 \\
\hline Cohabit without children & $-0.479 *$ & 0.619 & $-0.981 * * *$ & 0.375 & 0.142 & 1.153 & -0.165 & 0.848 & -0.143 & 0.867 & -0.351 & 0.704 \\
\hline
\end{tabular}




\begin{tabular}{|c|c|c|c|c|c|c|c|c|c|c|c|c|}
\hline Single male with children & -0.101 & 0.904 & -0.159 & 0.853 & $-0.459 *$ & 0.632 & -0.253 & 0.776 & -0.588 & 0.555 & -0.203 & 0.816 \\
\hline $\begin{array}{l}\text { Single male without } \\
\text { children }\end{array}$ & $-1.095 * * *$ & 0.335 & $-1.294 * * *$ & 0.274 & $-0.425 * * *$ & 0.654 & $-0.801 * * *$ & 0.449 & $-0.933 * * *$ & 0.393 & $-0.427^{*}$ & 0.652 \\
\hline $\begin{array}{l}\text { Single female with } \\
\text { children }\end{array}$ & -0.284 & 0.753 & $-0.788 * * *$ & 0.455 & -0.103 & 0.902 & $-0.445 * * *$ & 0.641 & 0.187 & 1.206 & -0.106 & 0.899 \\
\hline $\begin{array}{l}\text { Single female without } \\
\text { children }\end{array}$ & $-0.621 * * *$ & 0.537 & $-0.906 * * *$ & 0.404 & 0.059 & 1.061 & $-0.801 * * *$ & 0.449 & $-0.395 * *$ & 0.674 & -0.189 & 0.828 \\
\hline \multicolumn{13}{|c|}{ Income (reference category= 1 st quartile) } \\
\hline 2nd quartile & $0.561 * * *$ & 1.752 & $0.689 * * *$ & 1.992 & $0.673 * * *$ & 1.960 & $0.711 * * *$ & 2.036 & 0.142 & 1.153 & 0.042 & 1.043 \\
\hline 3rd quartile & $0.910 * * *$ & 2.484 & $1.251 * * *$ & 3.494 & $0.854 * * *$ & 2.349 & $1.042 * * *$ & 2.835 & 0.205 & 1.228 & -0.054 & 0.947 \\
\hline 4th quartile & $0.604 * * *$ & 1.829 & $1.659 * * *$ & 5.256 & $0.626^{* * *}$ & 1.870 & $1.168 * * *$ & 3.216 & 0.027 & 1.027 & $-0.420 *$ & 0.657 \\
\hline
\end{tabular}


Table 4: Binary Logistic Analysis of Debt Burdens (Reference Category= No)

\begin{tabular}{|c|c|c|c|c|}
\hline \multirow[b]{2}{*}{ Parameter } & \multicolumn{2}{|c|}{ Debt to Income Ratio $40 \%+$} & \multicolumn{2}{|c|}{60 or more Days Late } \\
\hline & Coef. & Odds ratio & Coef. & Odds ratio \\
\hline Intercept & $-2.904 * * *$ & & -0.672 & \\
\hline Age & $-0.013^{*}$ & 0.987 & $-0.018 * * *$ & 0.982 \\
\hline \multicolumn{5}{|c|}{ Level of education (reference category= less than a high school diploma) } \\
\hline High school diploma (or GED) & 0.119 & 1.126 & 0.339 & 1.404 \\
\hline Some college & 0.358 & 1.430 & $0.610^{*}$ & 1.840 \\
\hline Bachelor's degree & $0.710^{* *}$ & 2.034 & 0.237 & 1.267 \\
\hline Graduate or professional degree & $0.743 *$ & 2.102 & 0.069 & 1.071 \\
\hline \multicolumn{5}{|c|}{ Employment status (reference category= other groups not working) } \\
\hline Work for someone else & -0.015 & 0.985 & 0.360 & 1.433 \\
\hline Self-employed/partnership & $0.695^{*}$ & 2.004 & $0.700 *$ & 2.014 \\
\hline Retired/disabled & $-0.612 *$ & 0.542 & -0.111 & 0.895 \\
\hline \multicolumn{5}{|c|}{ Risk tolerance (reference category $=$ no) } \\
\hline Higher than average & 0.277 & 1.319 & 0.039 & 1.040 \\
\hline Average & 0.001 & 1.001 & -0.216 & 0.806 \\
\hline \multicolumn{5}{|c|}{ Health status(reference category $=$ poor $)$} \\
\hline Excellent & -0.019 & 0.981 & $-1.269 * * *$ & 0.281 \\
\hline Good & -0.083 & 0.920 & $-0.975 * * *$ & 0.377 \\
\hline Fair & -0.094 & 0.910 & $-0.620 *$ & 0.538 \\
\hline Expected to receive heritage & 0.050 & 1.051 & 0.140 & 1.150 \\
\hline \multicolumn{5}{|c|}{ Financial planning horizon (reference category= within next year) } \\
\hline Next few years & -0.023 & 0.977 & -0.110 & 0.896 \\
\hline Next 5-10 years & -0.177 & 0.838 & $-0.439 *$ & 0.645 \\
\hline Longer than 10 years & -0.160 & 0.852 & -0.432 & 0.649 \\
\hline \multicolumn{5}{|l|}{ Race (reference category $=$ white) } \\
\hline Black & $0.442 *$ & 1.556 & $0.341 *$ & 1.406 \\
\hline Hispanic & 0.405 & 1.499 & $-0.562 *$ & 0.570 \\
\hline Other & $0.643^{*}$ & 1.902 & -0.129 & 0.879 \\
\hline Homeownership & $2.639 * * *$ & 13.999 & -0.150 & 0.861 \\
\hline \multicolumn{5}{|c|}{ Family type (reference category= married with children) } \\
\hline Married without children & -0.318 & 0.728 & $-0.809 * *$ & 0.445 \\
\hline Cohabit with children & -0.025 & 0.975 & 0.007 & 1.007 \\
\hline Cohabit without children & -0.027 & 0.973 & -0.540 & 0.583 \\
\hline Single male with children & -0.009 & 0.991 & -0.049 & 0.952 \\
\hline Single male without children & -0.095 & 0.909 & $-0.912 * * *$ & 0.402 \\
\hline Single female with children & 0.120 & 1.127 & -0.085 & 0.919 \\
\hline Single female without children & -0.259 & 0.772 & $-0.796 * *$ & 0.451 \\
\hline \multicolumn{5}{|c|}{ Income (reference category $=1$ st quartile) } \\
\hline 2nd quartile & $-0.962 * * *$ & 0.382 & -0.014 & 0.986 \\
\hline 3rd quartile & $-2.162 * * *$ & 0.115 & $-0.480 *$ & 0.619 \\
\hline 4th quartile & $-3.220 * * *$ & 0.040 & $-1.194 * * *$ & 0.303 \\
\hline
\end{tabular}

Note: analysis of Survey of Consumer Finances 2016. ${ }^{*} p<.05,{ }^{* *} p<.01,{ }^{* * *} p<.001$. 